\title{
Ethanolic Extract of Psidium cattleianum as Intracanal Irrigation: An In vitro Study of Cell Viability
}

\section{Christine Men Martins ${ }^{1 *}$, Thayse Yumi Hosida ${ }^{2}$, Victor Eduardo de Souza Batista ${ }^{3}$, Ana Maria Sell ${ }^{4}$, Eloi Dezan-Junior ${ }^{5}$ and Mirian Marubayashi Hidalgo ${ }^{6}$}

\begin{abstract}
${ }^{1}$ Department of Dentistry, Santa Fé do Sul Dental School, Integrated Faculties of Santa Fé do Sul - FUNEC, Santa Fé do Sul, São Paulo, Brazil
${ }^{2}$ Department of Pediatric Dentistry and Public Health, Araçatuba Dental School, Univ. Estadual Paulista - UNESP, Araçatuba, São Paulo, Brazil

${ }^{3}$ Department of Dental Materials and Prosthodontics, Aracatuba Dental School, Univ Estadual Paulista - UNESP, Araçatuba, São Paulo, Brazil

${ }^{4}$ Department of Analyses Clinical and Biomedicine, Post Graduation Program of Biosciences and Physiopathology, State University of Maringá UEM, Maringá, Paraná, Brazil
\end{abstract}

${ }^{5}$ Department of Endodontics, Aracatuba Dental School, Univ. Estadual Paulista, Araçatuba - UNESP, Araçatuba, São Paulo, Brazil

${ }^{6}$ Department of Dentistry, State University of Maringá - UEM, Maringá, Paraná, Brazil

\begin{abstract}
*Corresponding author: Prof. Christine Men Martins, Department of Dentistry, Santa Fé do Sul Dental School, Integrated Faculties of Santa Fé do Sul - FUNEC 477, Mangara avenue, Santa Fé do Sul, São Paulo, Brazil - 15775-000; E mail: christinemen@hotmail.com
\end{abstract}

Article Type: Research, Submission Date: 12 December 2016, Accepted Date: 15 December 2016, Published Date: 27 June 2017.

Citation: Christine Men Martins, Thayse Yumi Hosida, Victor Eduardo de Souza Batista, Ana Maria Sell, Eloi Dezan-Junior, et al. (2017) Ethanolic Extract of Psidium cattleianum as Intracanal Irrigation: An In vitro Study of Cell Viability. J. Dent. Sci. Ther 1(3): 1-5. doi: https://doi.org/10.24218/jdst.2017.11.

Copyright: @ 2017 Christine Men Martins, et al. This is an open-access article distributed under the terms of the Creative Commons Attribution License, which permits unrestricted use, distribution, and reproduction in any medium, provided the original author and source are credited.

\section{Abstract}

The aim of this study was to evaluate the ethanolic extract of Psidium cattleianum biocompatibility by structural and functional cell viability maintenance. Cell viability was analyzed after $1 \mathrm{~h}, 3 \mathrm{~h}, 6 \mathrm{~h}, 10 \mathrm{~h}$ and $24 \mathrm{~h}$ of incubation by Exclusion Method with trypan blue and MTT assay, using human mononuclear cells (PBMC) and human periodontal ligament (PDL) cells in culture. Positive control used was RPMI cell culture medium and negative control was ethanol $80 \%$. The obtained data were subjected to statistical analysis at a significance level of 5\%. By trypan blue assay, ethanolic extract presented a homogeneous performance of PBMC from the $1 \mathrm{~h}$, with average viability between 30 and 50\% ( $>>0.05)$. By MTT assay, the results showed the efficacy of the ethanolic extract of Psidium cattleianum in maintaining the functional viability of the periodontal ligament cells to $10 \mathrm{~h}(\mathrm{p}>0.05)$, presenting values greater than the RPMI control. In both methods, it can be observed that the extract properties can neutralize the cytotoxic effect of its diluent ethanol $80 \%$, which showed average viability nearly zero ( $\mathrm{p}$ $<0.05)$. Thus, biocompatibility by structural and functional cell viability maintenance was considered acceptable to ethanolic extract of Psidium cattleianum and further studies should be performed to indicate its use as an alternative to irrigation solution traditionally used in everyday practice.

Keywords: Psidium, Cell survival, Materials testing.

\section{Introduction}

Endodontic treatment aimed to restore the normality of apical and periapical tissues [1-4] through a root canal system deep cleaning and disinfection, to control pathogenic microorganisms and the complete three-dimensional sealing using root canal sealers [5-7]. To achieve this goal, irrigation and aspiration of the root canal system, coupled with instrumentation, composes an important stage of radical endodontic treatment, the chemical mechanical preparation. At this stage, the infection is combated and the tissue inflammation can be reduced [8-10].

Currently, the use of rotatory systems has increased due to the ease, speed and practicality of instrumentation techniques, using rotary or reciprocating files as well as unique files [11-13], corroborating to an endodontic treatment in a single section [14]. In this context, the using of a good irrigant solution is becoming highly necessary, since its action time is decreased.

An ideal irrigant solution should remove the pulp tissue debris and necrotic tissue, as well as the smear layer. Thus, it will assist in the emptying of the pulp cavity, creating a space for placing the further intracanal medication and/or obturation. Furthermore, the irrigant agent must lubricate the root canal. In cases of pulp necrosis treatment, the irrigating solution should act as a factor of antimicrobial activity and disinfectant. For the biopulpectomy treatment, it must assist in removing biological tissue and bleeding stagnation. Regardless of the type of treatment to be 
Citation: Christine Men Martins, Thayse Yumi Hosida, Victor Eduardo de Souza Batista, Ana Maria Sell, Eloi Dezan-Junior, et al. (2017) Ethanolic Extract of Psidium cattleianum as Intracanal Irrigation: An In vitro Study of Cell Viability. J. Dent. Sci. Ther 1(3): 1-5. doi: https://doi.org/10.24218/ jdst.2017.11.

performed, the irrigating solution must present biocompatibility, in order to keep the integrity of the periapical structures, not promoting irritation of the remaining pulp tissue and allowing repair [15-18].

Several substances may be used as irrigating agent, such as hemostatic agents, halogenated compounds, detergents, chelators, acids and peroxides; however, there is not a substance that has the characteristics to be considered ideal. Currently, there is a trend toward the use of natural substances and medicinal plants $[19,20]$ and within this context, the results presented in previous studies with Psidium cattleianum aroused interest in its use as intracanal irrigant solution during endodontic treatment. Psidium cattleianum seems to be promising as intracanal medication during endodontic treatment [21-26]. Aqueous and ethanol extracts of Psidium cattleianum have shown remarkable antibacterial activity against oral microbiota, anti-inflammatory and potential anticariogenic effects, and tissue biocompatibility [22-24,26]. However, determining the use and clinical application of this extract requires testing for cytotoxicity, sensitization [25], anti-inflammatory and antimicrobial activities [21,22,24,26], among other issues.

The literature shows that there is still no knowledge of cellular cytotoxicity of ethanol extract. Therefore, the aim of this study was to evaluate the ethanolic extract of Psidium cattleianum biocompatibility by structural and functional cell viability maintenance. The hypothesis tested was that ethanolic extract of Psidium cattleianum would present biocompatibility greater than cell culture medium.

\section{Material and Methods}

\section{Extract and controls}

The ethanolic extract was prepared accordingly to a described protocol [22]. Culture medium Roswell Park Memorial Institute 1640 (RPMI - Gibco ${ }^{\oplus}$, Life Technologies, USA) was used as a positive control and ethanol $80 \%$ served as negative control.

\section{Human mononuclear cells (PBMC)}

To obtain the PBMC, $15 \mathrm{~mL}$ of venous blood from 4 donors was obtained aseptically in heparinized tubes with 2 drops of Liquemine ${ }^{\circledast}$ (Roche, Switzerland). The cells were isolated by the method described by literature $[26,27]$. The tubes were centrifuged and the interface between plasma and red blood cells were collected and diluted in sterile phosphate-buffered saline (PBS) and placed over a discontinuous gradient Histopaque (Sigma Chemical Co., USA). After further centrifugation, the leukocytes were removed via Pasteur pipette and transferred to another tube. Then the washing process was carried out 3 times with PBS. The cell precipitated was resuspended in RPMI (Life Technologies, USA).

\section{Human periodontal ligament cells maintained in culture} (PDL)

The PDL cells were kindly provided by the laboratory of Applied
Virology, Santa Catarina Federal University. The cells were kept in an incubator $\left(5 \% \mathrm{CO} 2 / 95 \%\right.$ humidity, $\left.37^{\circ} \mathrm{C}\right)$ in cell culture bottles (TTP Techno Plastic Products, Switzerland) containing Dulbecco's MEM (DMEM - Cultilab, Brazil) supplemented with $10 \%$ fetal bovine serum (FBS - Cultilab, Brazil) and 1\% of a combination of penicillin 10,000 UI/mL, streptomycin 20 $\mathrm{mg} / \mathrm{mL}$ and amphotericin B $2 \mathrm{mg} / \mathrm{L}$ (PSA - Cultilab, Brazil). The culture medium was changed every 48 or $72 \mathrm{~h}$. After cell confluence the trypsinization was done using $0.25 \%$ trypsin solution and ethylenediaminetetraacetic acid (EDTA - Sigma Chemical Co., USA) for several minutes to release the cells. After neutralization with RPMI (Life Technologies, USA), the cell precipitate was washed, dissolved in a fresh culture medium, and aliquoted in bottles. Each trypsinization yielded a new passage and throughout the experimental period when confluence, cells were replicated to maintain the culture's optimal viability. The experiments were performed when cells were between the $11^{\text {th }}$ and $12^{\text {th }}$ passages [28].

\section{Trypan Blue assay}

The viability was determined by microscopic observation of the cells excluded by staining with trypan blue, a vital stain derived from toluidine. These 2 types of cells in a final concentration of $1 \times 10^{6}$ cells $/ \mathrm{mL}$ were incubated in ethanolic extract of Psidium cattleianum or controls during $24 \mathrm{~h}$ at $25^{\circ} \mathrm{C}$. Samples were collected at 1, 3, 6, 10 and $24 \mathrm{~h}$ and analyzed in a Neubauer chamber with an equal volume staining. Cells were considered not viable when impregnated by staining or when degenerated. Three previously trained observers performed the readings under an optical microscope and expressed the results as percentages. They repeated the process 4 times.

\section{MTT assay}

The cells were adjusted to $1 \times 10^{4}$ cells $/ \mathrm{ml}$ in RPMI (Life Technologies, USA) with 10\% FBS (Cultilab, Brazil) and 1\% PSA (Cultilab, Brazil), and seeded in 96-well plates (TPP Techno Plastic Products, Switzerland). After incubation (5\% $\mathrm{CO}_{2}$ and $95 \%$ humidity at $37^{\circ} \mathrm{C}$ incubator) for $24 \mathrm{~h}$ for cell adhesion, the culture medium was discarded, and the extract or control was added. After the incubation times of 1, 3, 6, 10 and $24 \mathrm{~h}$, the experimental medium was removed and MTT solution was added (5 mg/mL, MTT-thiazole blue, Sigma Chemical Co., USA). The plates stayed in the incubator during $3 \mathrm{~h}$. Then the MTT solution was removed and dimethylsulfoxide (DMSO - Merck, Brazil) was added to dissolve formazan crystals. Cell viability was determined by reading the absorbance of the wells under the wavelength of $550 \mathrm{~nm}$ (ASYS Expert Plus Microplate Reader, Biochrom, UK). The test was also performed in triplicate with 4 repeats.

\section{Statistical analysis}

Data on the percentage of viable cells were obtained by means of exclusion with trypan blue and PDL cells and PBMC in culture were collected for the groups in a time-dependent manner. To 
Citation: Christine Men Martins, Thayse Yumi Hosida, Victor Eduardo de Souza Batista, Ana Maria Sell, Eloi Dezan-Junior, et al. (2017) Ethanolic Extract of Psidium cattleianum as Intracanal Irrigation: An In vitro Study of Cell Viability. J. Dent. Sci. Ther 1(3): 1-5. doi: https://doi.org/10.24218/ jdst.2017.11.

analyze these results, it was used linear mixed effects models with PROC NLMIXED of SAS version 9. The results of the viability of PDL cell cultures by MTT method were subjected to ANOVA Factorial through SAS software 9.3.n. The level of statistical significance was set at $5 \%$ for all analyses.

\section{Results}

\section{Cell viability for different media in which cells were stored}

The averages of cell viabilities maintained in different media, regardless of time, are shown in Table. By Trypan Blue methodology with PBMC, the ethanolic extract presented the viability near $50 \%$, higher than the ethanol control $(p<0.05)$. The optical density values, which represent the viability of periodontal ligament cells analyzed by MTT, the extract averaged was slightly more than twice compared to the positive control RPMI. Control of alcohol extract showed almost no optical density ( $p>0.05)$.

\section{Cell viability after incubation and throughout the experimental period}

The cell viability maintained in the test medium and its control over a 24 hours' period is described in Figure. Figure A represents Trypan Blue assay with PBMCs. Within the first hour of incubation, the cells maintained in ethanolic extract showed a reduction in cell viability and thereafter maintained that viability with homogeneous performance over time. The control solution had cell viability below $10 \%$, differing statistically from other medias ( $\mathrm{p}<0.05)$. Figure B represents the optical density values obtained by periodontal ligament cells analyzed by MTT. The results have demonstrated superior functional performance to ethanolic extract until 10 hours later, suffering a drop in 24 hours. Negative control ethanol presented lower values since the first hour $(\mathrm{p}<0.05)$.

Table: Average of cell viability for different media in which cells were stored

\begin{tabular}{|l|c|c|}
\hline & Trypan Blue Assay (\%) - PBMC & MTT (O.D.) ${ }^{1}$ - PDL \\
\hline Ethanolic extract of Psidiumcattleianum & 49 & 1,38 \\
\hline RPMI (positive control) & 92 & 0,55 \\
\hline Ethanol 80\% (negative control) & $17,3^{*}$ & 0,01 \\
\hline
\end{tabular}

${ }^{1}$ O.D.=optical density. *Statistically significant difference between the negative control - ethanol $80 \%$ - and other media $(p<0.05)$ for the Trypan Blue assay

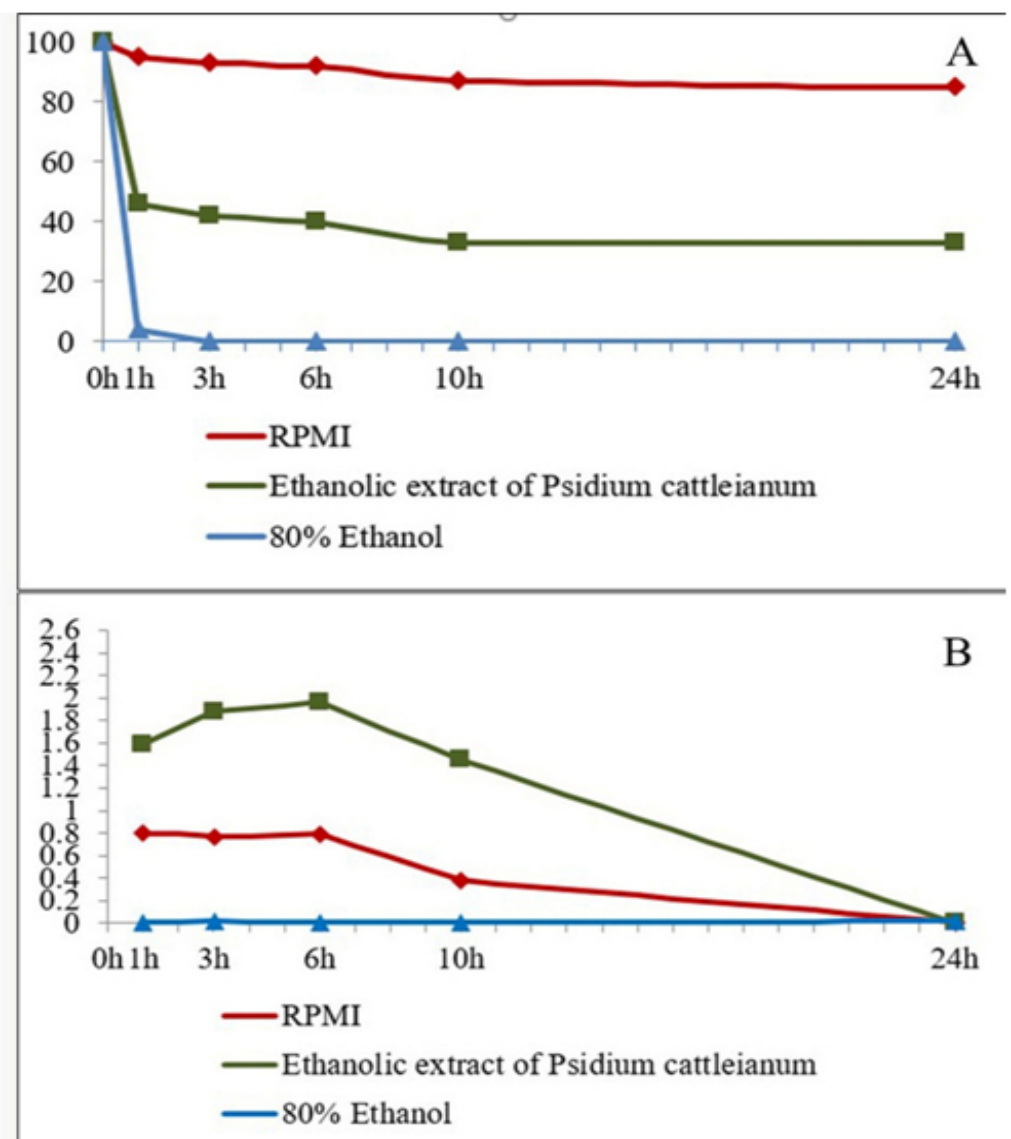

Figure: Relative percentage of average viability of cells incubated in different media throughout the experimental period. A-Exclusion methodology by Trypan Blue dye with PBMC; B- MTT Methodology with the PDL. *Statistically significant difference from the negative control Alcohol $80 \%$ compared to another media 
Citation: Christine Men Martins, Thayse Yumi Hosida, Victor Eduardo de Souza Batista, Ana Maria Sell, Eloi Dezan-Junior, et al. (2017) Ethanolic Extract of Psidium cattleianum as Intracanal Irrigation: An In vitro Study of Cell Viability. J. Dent. Sci. Ther 1(3): 1-5. doi: https://doi.org/10.24218/ jdst.2017.11.

\section{Discussion}

This research aimed to verify cellular and functional viability of PBMC and PDL kept in ethanol extract of Psidium cattleianum over 24. Cell viability was homogeneous over time, averaging between 30 and 50\% for PBMC. The functional viability of PDL was high until 10 hours, with a considerable drop after this period. Ethanolic extract neutralized part of the cytotoxic effect of its diluent $80 \%$ alcohol. However, the hypothesis tested was rejected, because even though ethanolic extract of Psidium cattleianum presented good biocompatibility, it was not greater than cell culture medium.

PBMC were used due to its ease and speed way of obtaining. PDL cells were used to approach in vitro research with the reality, once they are the cells directly involved in the healing after endodontic treatment [16]. These cells also permit standardization of cell concentration, by the way it is easy to detect tiny possible changes.

Trypan blue assay is commonly used in assessing viability and allows analysis of physical integrity of the cell membrane [16,27-29]. However, this methodology does not evaluate the real metabolic capacity of cell. To overcome this gap, it was carried out the MTT assay, quantifying the reduction of MTT salt. Through metabolism, MTT salt becomes formazan salt, which is purplish and soluble in DMSO. This makes it possible to quantify cellular metabolic activity via NADPH-dependent oxidoredutases. Reduction of MTT to formazan is directly proportional to mitochondrial activity and cell viability [28].

The viability of PBMC maintained in the ethanolic extract of Psidium remained homogeneous over time, averaging from $30 \%$ to $50 \%$ lower than the control RPMI. The RPMI is salts mixture enriched with aminoacids, vitamins and other essential components for cell growth which acts as a nutrient solution. Its $\mathrm{pH}$ and osmolarity are ideal for cell culture, usually being used as a positive control for the experiment. These cells maintained in ethanolic extract of Psidium showed a lower viability than in RPMI control, even though no statistical difference. The homogeneity was observed in the results from the first time when there was a reduction on viability.

The functional viability of PDL was two times higher when maintained in the extract than in RPMI, and increased after 10h. This high functional viability can be justified because of its natural antioxidants [30], and the production and release of factor growth mediators.

Unlike RPMI, $80 \%$ ethanol is considered unfavorable for cell culture media due to protein denaturation, cell lysis and cytotoxic effect [25]. However, comparing 80\% ethanol with ethanolic extract of Psidium cattleianum, it can be stated that Psidium neutralized by $50 \%$ the harmful effect of ethanol.

In addition, to maintaining the integrity of the membrane and the functional metabolic activity of the cells, ethanolic extract has been shown to have antimicrobial activity and being able to influence the capacity demineralization of hydroxyapatite by microorganisms [25]. Brighenti et al, [22] showed enamel reduction and demineralization, acidogenic potential, viability for microorganisms and the production of extracellular polysaccharide.

Thinking about Psidium cattleianum uses as an endodontic irrigant, it can be observed that it presents acceptable cytotoxicity and other properties previously described, as its anti-inflammatory and anti-microbial power. Thus, the results demonstrated that the ethanolic extract could maintain the PBMC viability from $30 \%$ to $50 \%$ with homogenous results throughout the experimental period and maintained PDL functional viability higher than the positive control and deactivates the cytotoxic effect of its diluent, $80 \%$ ethanol.

\section{Conclusion}

Biocompatibility by structural and functional cell viability maintenance was considered acceptable to ethanolic extract of Psidium cattleianum. The results are promising and further studies should be conducted to his appointment as a possible alternative to irrigating solutions traditionally used in everyday practice.

\section{Acknowledgements}

The project was approved by the Ethics Committee in Research Involving Humans from the Maringa State University, with the protocol number CAAE: 0108.0.093.000-10.

The authors would like to express gratitude to:

Univ. Estadual Paulista - UNESP, Araçatuba Dental School, Araçatuba, São Paulo, Brazil.

Universidade Estadual de Maringá - UEM, School of Dentistry, Maringá, Paraná, Brazil.

\section{References}

1. Holland R, de Mello W, Nery MJ, Bernabe PF, de Souza V. Reaction of human periapical tissue to pulp extirpation and immediate root canal filling with calcium hydroxide. Journal of Endodontics. 1977; 3:63-67.

2. Katebzadeh N, Sigurdsson A, Trope M. Radiographic evaluation of periapical healing after obturation of infected root canals: an in vivo study. Journal of Endodontics. 2000; 33(1):60-66.

3. Holland R, Otoboni Filho JA, de Souza V, Nery MJ, Bernabé PF, Dezan $\mathrm{E} J \mathrm{~J}$. A comparison of one versus two appointment endodontic therapy in dogs' teeth with apical periodontitis. Journal of Endodontics. 2003; 29(2):121-124.

4. Nakamura H. Success rate of endodontic treatment of teeth with vital and nonvital pulps. A meta-analysis. Oral Surg Oral Med Oral Pathol Oral Radiol Endod. 2004; 97(1):95-99.

5. Gomes-Filho JE, Bernabé PFE, Nery MJ, Otoboni-Filho JA, DezanJunior E, Costa MMTM, et al. Reaction of rat connective tissue to a new calcium hydroxide-based sealer. Oral Surg Oral Med Oral Pathol Oral Radiol Endod. 2008; 106:e71-e76.

6. Gomes-Filho JE, Watanabe S, Gomes AC, Faria MD, Lodi CS, Penha $\mathrm{SH}$. Evaluation of the effects of endodontic materials on fibroblast viability and cytokine production. Journal of Endodontic. 2009; 35(11):1577-1579. 
Citation: Christine Men Martins, Thayse Yumi Hosida, Victor Eduardo de Souza Batista, Ana Maria Sell, Eloi Dezan-Junior, et al. (2017) Ethanolic Extract of Psidium cattleianum as Intracanal Irrigation: An In vitro Study of Cell Viability. J. Dent. Sci. Ther 1(3): 1-5. doi: https://doi.org/10.24218/ jdst.2017.11.

7. Bernades RA, Campelo AA, Junior DS, Pereira LO, Duarte $M A H_{\text {, }}$ Moraes IG, et al. Evaluation of the flow rate of 3 endodontic sealers: Sealer 26, AH Plus, and MTA Obtura. Oral Surg Oral Med Oral Pathol Oral Radiol Endod. 2010; 109:e47-e49.

8. Batista VE, Olian DD, Mori GG. Diffusion of hydroxyl ions from calcium hydroxide and Aloe vera pastes. Braz Dent J. 2014;25(3):212216.

9. Kawashima N, Wadachi R, Suda H, Yeng T, Parashos P. Root canal medicaments. International Dental Journal. 2009; 59(1):5-11.

10. Mohammadi Z, Abbott PV. Antimicrobial substantivity of root canal irrigants and medicaments: a review. Australian Endodontic Journal. 2009; 35(3):131-139.

11. Basmaci F, Oztan MD, Kiyan M. Ex vivo evaluation of various instrumentation techniques and irrigants in reducing $\mathrm{E}$. faecalis within root canals. Int Endod J. 2013:46(9):823-830.

12. Nabeshima CK, Caballero-Flores $\mathrm{H}$, Cai S, Aranguren J, Borges Britto ML, de Lima Machado ME. Bacterial Removal Promoted by 2 Single-file Systems: Wave One and One Shape. J Endod. 2014; 40(12): 1995-1998. doi: 10.1016/j.joen.2014.07.024.

13. Martinho FC, Gomes AP, Fernandes AM, Ferreira NS, Endo MS, Freitas LF, et al. Clinical comparison of the effectiveness of singlefile reciprocating systems and rotary systems for removal of endotoxins and cultivable bacteria from primarily infected root canals. J Endod. 2014; 40(5):625-629.

14. Vera J, Siqueira JF Jr, Ricucci D, Loghin S, Fernández N, Flores B, et al. One- versus two-visit endodontic treatment of teeth with apical periodontitis: a histobacteriologic study. J Endod. 2012; 38(8):1040-1052.

15. Misuriya A, Bhardwaj A, Bhardwaj A, Aggrawal S, Kumar PP, Gajjarepu S. A comparative antimicrobial analysis of various root canal irrigating solutions on endodontic pathogens: an in vitro study. J Contemp Dent Pract 2014; 15(2):153-160.

16. Willershausen I, Wolf TG, Schmidtmann I, Berger C, Ehlers V, Willershausen B, et al. Survey of root canal irrigating solutions used in dental practices within Germany. Int Endod J. 2015; 48(7):654660.

17. Cruz A, Vera J, Gascón G, Palafox-Sánchez CA, Amezcua O, Mercado $G$. Debris remaining in the apical third of root canals after chemomechanical preparation by using sodium hypochlorite and glyde: an in vivo study. J Endod. 2014 ; 40(9):1419-1423.

18. Ravikumar J, Bhavana V, Thatimatla C, Gajjarapu S, Reddy SG, Reddy BR. The effect of four different irrigating solutions on the shear bond strength of endodontic sealer to dentin - An In-vitro study. J Int Oral Health. 2014; 6(1):85-88
19. Verma MK, Pandey RK, Khanna R, Agarwal J. The antimicrobial effectiveness of $25 \%$ propolis extract in root canal irrigation of primary teeth. J Indian Soc Pedod Prev Dent. 2014; 32(2):120-124.

20. World Health Organization. WHO Traditional Medicine Strategy 2002-2005, Geneva: WHO; 2002.

21. Alves PM, Queiroz LM, Pereira JV, Pereira MS. In vitro antimicrobial, antiadherent and antifungal activity of Brazilian medicinal plants on oral biofilm microorganisms and strains of the genus Candida. Revista da Sociedade Brasileira de Medicina Tropical. 2009; 42(2):222-224.

22. Brighenti $F L$, Luppens $S B I$, Delbem ACB, Deng DM, Hoogenkamp MA, Gaetti-Jardim Jr E, et al. Effect of Psidium cattleianum leaf extract on Streptococcus mutans viability, protein expression and acid production. Caries Research. 2008; 42:148-154.

23. Scur MC, Pinto FG, Pandini JA, Costa WF, Leite CW, Temponi LG. Antimicrobial and antioxidant activity of essential oil and different plant extracts of Psidium cattleianum Sabine. Braz J Biol. 2016; 76(1):101-108.

24. Jaiarj $P$, Khoohaswan $P$, Wongkrajang $Y$, Peungvicha $P$, Suriyawong $\mathrm{P}$, Saraya ML, et al. Anticough and antimicrobial activities of Psidium guajava Linn. leaf extract. Journal of Ethnopharmacology. 1999; 67:203-212.

25. Lozoya X, Meckes M, Aboud-Zaid M, Tortoriello J, Nozzolillo C, Amason JT. Quercetin glycosides in Psidium guajava $\mathrm{L}$. leaves and determination of spasmolytic principle. Archives of Medical Research. 1994; 25:11-15.

26. Menezes TEC, Delbem ACB, Brighenti FL, Okamoto AC, GaettiJardim Jr E. Protective efficacy of Psidium cattleianum and Myracrodruon urundeuva aqueous extracts against caries development in rats. Pharmaceutical Biology. 2010; 48:300-305.

27. Boyum A. Isolation of mononuclear cells and granulocytes from human blood. Scandinavian Journal of Clinical and Laboratory Investigation. 1968; 21:77-89.

28. Oh YH, Che ZM, Hong JC, Lee EJ, Lee SJ, Kim J. Cryopreservation of human teeth for future organization of a tooth bank--a preliminary study. Cryobiology. 2005; 51(3):322-329.

29. Blömlof L, Otteskog P. Viability of human periodontal ligament cells after storage in milk or saliva. Scand J Dent Res. 1980; 88:436-440.

30. Akinola OB, Oladosu OS, Dosumu OO. Spermatoprotective activity of the leaf extract of Psidium guajava Linn. Niger Postgrad Med J. 2007; 14(4):273-276. 